\title{
GAMBARAN KADAR ASAM URAT DARAH PADA MAHASISWA ANGKATAN 2011 FAKULTAS KEDOKTERAN UNIVERSITAS SAM RATULANGI DENGAN INDEKS MASSA TUBUH $18,5-22,9 \mathrm{~kg} / \mathrm{m}^{2}$
}

\author{
${ }^{1}$ Enika Tilaar \\ ${ }^{2}$ Stefana Kaligis \\ ${ }^{2}$ Diana Purwanto
}

\author{
${ }^{1}$ Kandidat Skripsi Fakultas Kedokteran Universitas Sam Ratulangi Manado \\ ${ }^{2}$ Bagian Biokimia Fakultas Kedokteran Universitas Sam Ratulangi Manado \\ Email: enikatilaar@yahoo.com
}

\begin{abstract}
Increased uric acid levels (hyperuricemia) play a role in the level of morbidity in several diseases. The prevalence of hyperuricemia in Manado and Minahasa is high compared to other regions in Indonesia. Hyperuricemia can occur at a young age. The purpose of this study is to determine the blood levels of uric acid at students Faculty of Medicine year 2011, Sam Ratulangi University with body mass index of $18,5-22,9 \mathrm{~kg} / \mathrm{m}^{2}$. This is a descriptive study with purposive sampling as the sampling method. There were 31 respondents that participated in this study. From 31 respondents, 30 respondents $(96,8 \%)$ had normal blood uric acid levels and only one (3,2\%) had high level of blood uric acid (hyperuricemia). Conclusion: majority (96,8\%) of students Faculty of Medicine year 2011, Sam Ratulangi University with body mass index of $18,5-22,9 \mathrm{~kg} / \mathrm{m}^{2}$ has normal blood uric acid levels.
\end{abstract}

Keywords: BMI 18,5-22,9 kg/m², Hyperuricemia, Uric Acid.

\begin{abstract}
Abstrak: Kadar asam urat yang meningkat (hiperurisemia) berperan dalam tingkat morbiditas pada beberapa penyakit. Prevalensi hiperurisemia di Manado dan Minahasa termasuk tinggi dibandingkan daerah lain di Indonesia. Hiperurisemia dapat terjadi pada usia muda. Tujuan penelitian ini untuk mengetahui kadar asam urat darah pada mahasiswa angkatan 2011 Fakultas Kedokteran Universitas Sam Ratulangi dengan indeks massa tubuh (IMT) 18,5-22,9 $\mathrm{kg} / \mathrm{m}^{2}$. Penelitian ini bersifat deskriptif dengan pengambilan sampel menggunakan metode purposive sampling. Penelitian ini diikuti oleh 31 responden. Dari 31 responden ditemukan jumlah responden yang memiliki kadar asam urat normal sebanyak 30 responden $(96,8 \%)$ dan hiperurisemia sebanyak satu responden (3,2\%). Simpulan: sebagianbesar $(96,8 \%)$ responden mahasiswa angkatan 2011 Fakultas Kedokteran Universitas Sam Ratulangi dengan indeks massa tubuh $18,5-22,9 \mathrm{~kg} / \mathrm{m}^{2}$ mempunyai kadar asam urat darah dalam batas yang normal.
\end{abstract}

Kata Kunci: AsamUrat, Hiperurisemia, IMT 18,5-22,9 kg/m².

Pada dua dekade terakhir ini, kejadian dari hiperurisemia dan gout mengalami peningkatan ganda. ${ }^{1}$ Peningkatan prevalensi gout saat ini telah mencakup kasus yang lebih rumit dengan adanya penggabungan dengan sindroma metabolik, obesitas, serta kondisi lainnya yang menyebabkan komorbiditas. $^{2}$ Hiperurisemia sendiri turut berperan dalam tingkat morbiditas pada keadaan gagal ginjal kronik, hipertensi, serta penyakit kardiovaskuler. ${ }^{3} \mathrm{Di}$ Amerika Serikat khusus usia 20-29 tahun, prevalensi hiperurisemia sebesar $18,6 \%$ di tahun 2007-2008. ${ }^{4}$ Prevalensi hiperurisemia pada laki-laki usia kurang dari 45 tahun adalah 17,3\% pada Januari 2008 sampai Juni 2010 di daerah Gwangju dan Jeonnam, Korea. ${ }^{5}$ Di Indonesia, angka prevalensi hiperuri- 
semia juga bervariasi. Prevalensi hiperurisemia di Bali pada tahun 2009 adalah $12,22 \%$ pada usia $13-85$ tahun, pada pria $15 \%$ dan pada wanita 6,7\%. ${ }^{6}$ Di Minahasa diperoleh angka kejadian hiperurisemia pada usia dewasa muda yakni 34,30\%, pada pria $46,58 \%$ dan pada wanita 23,31\%. ${ }^{7}$ Hiperurisemia merupakan suatu keadaan yang disebabkan oleh produksi yang berlebihan, penurunan ekskresi dari asam urat, maupun kombinasi dari kedua keadaan tersebut. ${ }^{8}$ Secara klinis hiperurisemia mempunyai arti penting karena dapat menyebabkan artritis gout, gout nefropati, dan tofi. ${ }^{9}$ Pada keadaan normal, kadar asam urat serum anak-anak biasanya lebih rendah. Kadar asam urat pada laki-laki mulai akan meningkat saat memasuki usia pubertas, tetapi pada wanita akan tetap rendah sampai menopause. ${ }^{10}$ Penelitian ini bertujuan untuk mengetahui gambaran kadar asam urat darah pada mahasiswa angkatan 2011 di Fakultas Kedokteran Universitas Sam Ratulangi Manado dengan IMT 18,5-22,9 kg/m².

\section{METODE PENELITIAN}

Penelitian ini merupakan penelitian survei deskriptif. Sampel penelitian berjumlah 31 orang responden dengan menggunakan metode pengambilan sampel Purposive Sampling, yang memenuhi kriteria yakni: mahasiswa Fakultas Kedokteran Unsrat Angkatan 2011, IMT $18,5-22,9 \mathrm{~kg} / \mathrm{m}^{2}$, usią 18 tahun, dan bersedia menjadi responden. Pengambilan sampel dilakukan menggunakan kuesioner untuk mendapatkan sampel yang sesuai dengan kriteria, kemudian dilakukan pengukuran berat badan dan tinggi badan, setelah itu sampel diminta untuk mengisi dan menandatangani informed consent. Pengukuran Indeks Massa Tubuh (IMT) menggunakan rumus berat badan dalam satuan kilogram (kg) dibagi tinggi badan dalam satuan meter kuadrat $\left(\mathrm{m}^{2}\right)$ dan penilaian kadar asam urat darah dilakukan berdasarkan pengambilan darah pada vena mediana cubiti setelah sampel berpuasa selama 10-12 jam. Penelitian ini menggunakan klasifikasi Indeks Massa Tubuh (IMT) berdasarkan kriteria World Health Organization (WHO) modifikasi AsiaPasifik. ${ }^{11}$ Kadar asam urat di atas $7 \mathrm{mg} / \mathrm{dL}$ pada laki-laki dan $6 \mathrm{mg} / \mathrm{dL}$ pada perempuan dipergunakan sebagai batasan kadar hiperurisemia. ${ }^{9}$

\section{HASIL PENELITIAN}

Berdasarkan jenis kelamin diperoleh data bahwa dari 31 orang responden ditemukan 22 orang responden perempuan $(71,0 \%)$ dan 9 orang responden laki-laki (29,0\%) (Tabel 1).Dari 31 orang responden ditemukan ada satu responden (3,2\%) yang memiliki kadar asam urat darah yang tinggi dan 30 responden (96,8\%) yang memiliki kadar asam urat darah yang normal (Tabel 2).

Berdasarkan distribusi jenis kelamin, pada laki-laki terdapat satu responden (3,2\%) yang memiliki kadar asam urat darah yang tinggi dan delapan responden (25,8\%) yang memiliki kadar asam urat darah yang normal. Pada jenis kelamin perempuan semuanya $(71,0 \%)$ memiliki kadar asam urat yang normal (Gambar 1).

Tabel1.Distribusi responden berdasarkan jenis kelamin.

\begin{tabular}{ccc}
\hline JenisKelamin & Jumlah (n) & Persentase (\%) \\
\hline Laki-laki & 9 & 29,0 \\
Perempuan & 22 & 71,0 \\
Total & 31 & 100 \\
\hline
\end{tabular}


Tabel 2. Distribusi responden berdasarkan kadar asam urat darah.

\begin{tabular}{ccc}
\hline Kadar Asam Urat Darah & $\begin{array}{c}\text { Jumlah } \\
\text { (n) }\end{array}$ & $\begin{array}{c}\text { Persentase } \\
\text { (\%) }\end{array}$ \\
\hline Normal & 30 & 96,8 \\
Tinggi & 1 & 3,2 \\
Total & 31 & 100 \\
\hline
\end{tabular}

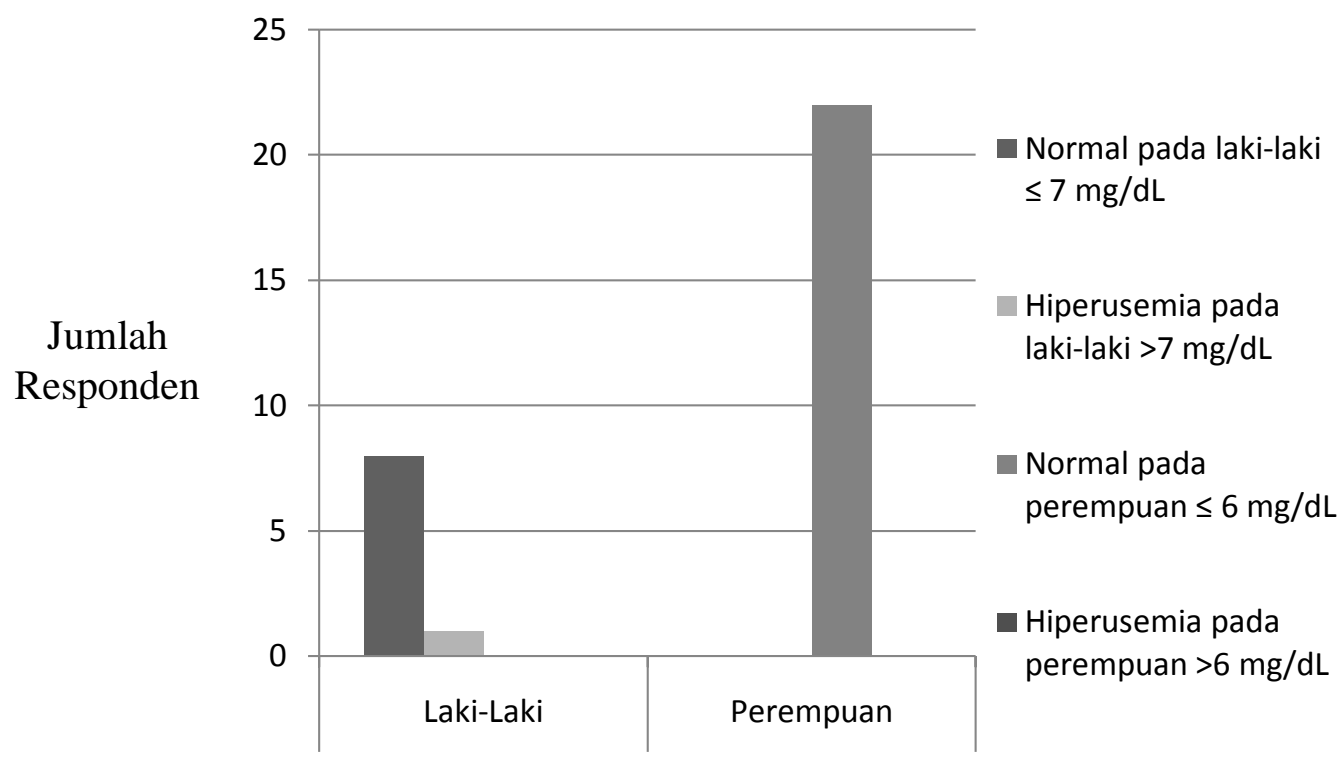

Gambar 1. Diagram distribusi jenis kelamin responden berdasarkan kadar asam urat darah.

\section{BAHASAN}

Pada penelitian ini, dari 31 orang responden terdapat 30 responden laki-laki dan perempuan $(96,8 \%)$ yang memiliki kadar asam urat darah yang normal, dan hanya satu responden laki-laki (3,2\%) yang memiliki kadar asam urat di atas normal atau hiperurisemia. Pada semua responden perempuan $(71,0 \%)$ dalam penelitian ini didapati hasil kadar asam urat darah yang normal. Hal ini mendukung teori di mana kadar asam urat darah pada perempuan premenopause lebih rendah dibandingkan pada post-menopause, karena adanya estrogen yang berperan dalam meningkatkan ekskresi asam urat melalui ginjal. ${ }^{12}$ Pada keadaan normal, kadar asam urat serum anak-anak biasanya lebih rendah yakni sekitar 3,5 mg/dL. ${ }^{13}$ Kadar asam urat pada laki-laki mulai akan meningkat saat memasuki usia pubertas. ${ }^{10}$ Pada penelitian ini didapati delapan (25,8\%) responden laki-laki memiliki kadar asam urat normal.

Pada penelitian ini didapati saturesponden (3,2\%) dengan IMT normal mengalami hiperurisemia. Berdasarkan penelitian di Amerika Serikat yang dilakukan oleh Choi pada usia $\geq 20$ tahun, didapati prevalensi sebesar 59,0\% untuk kadar asam urat $\geq 10 \mathrm{mg} / \mathrm{dL}$ pada responden yang memiliki IMT normal. ${ }^{14}$

Satu responden yang mengalami hiperurisemia pada penelitian ini berjenis kelamin laki-laki. Berdasarkan hasil penelitian sebelumnya, kejadian hiperurisemia lebih sering terjadi pada jenis kelamin laki-laki. Pada penelitian yang dilakukan di Hangzhou, China oleh Cai tahun 20072008 pada usia 20-80 tahun diperoleh 
angka kejadian hiperurisemia yakni 23,7\% pada laki-laki dan 5,3\% pada perempuan. ${ }^{15}$ Pada penelitian yang dilaku-kan oleh Premgamone di Khon Kaen, Thailand pada usia 15-24 tahun prevalensi hiperurisemia pada laki-laki sebesar $12,77 \%$, sedangkan pada wanita $5,08 \%{ }^{16}$

Responden yang mengalami hiperurisemia pada penelitian ini termasuk dalam kelompok usia muda. Peningkatan kadar asam urat darah (hiperurisemia) pada usia muda $\leq$ ( 30 tahun) kemungkinan disebabkan oleh adanya kerusakan genetik dalam sintesis asam urat. ${ }^{17}$ Hiperurisemia yang terjadi dapat disebabkan oleh peningkatan produksi, penurunan ekskresi asam urat, maupun kombinasi keduanya. ${ }^{8}$ Pada kebanyakan penelitian epidemiologi dari gout dan artritis, riwayat keluarga dengan gout dan nefrolitiasis dijumpai sebesar 25\% sampai 30\%, dan sebagian besar dari mereka mengalami penurunan ekskresi sebagai penyebab dari hiperurisemia. ${ }^{17}$ Penelitian yang dilakukan oleh Rotty di daerah Minahasa tahun 1999 pada usia dewasa muda didapati angka prevalensi hiperurisemia dengan riwayat keluarga menderita nyeri sendi yakni sebesar 38,86\%. ${ }^{7}$

Penyebab paling sering dari gout yang terjadi pada usia muda yakni defisiensi enzim hipoxantin-guanin fosforibosil transferase (HGPRTase) dan aktivitas berlebihan dari fosfori bosil pirofosfat (PRPP) sintetase. ${ }^{17}$ Pada penelitian laporan kasus yang dilakukan oleh García-Pavía di Spanyol dengan sampel seorang perempuan berusia 24 tahun yang mengalami hiperurisemia sejak berusia 11 tahun. Pada penelitian enzimatik dan genetik tersebut didapati adanya aktivitas yang berlebihan dari enzim fosforibosil fosfat sintetase sebagai penyebab dari produksi yang berlebihan dari asam urat pada perempuan usia muda tersebut. ${ }^{18}$

Pada responden yang mengalami hiperurisemia ini, pemeriksaan lanjutan yang dapat dilakukan berupa pemeriksaan kadar asam urat urin per 24 jam untuk mengetahui penyebab hiperurisemia yang terjadi berhubungan dengan produksi yang berlebihan ataupun ekskresi asam urat yang berkurang. Pemeriksaan kadar asam urat urin per 24 jam tidak biasa dilakukan pada praktik klinik, akan tetapi dapat dipertimbangkan untuk dilakukan pada pasien yang memiliki riwayat gout dan batu ginjal dalam keluarga serta onset gout yang terjadi pada usia muda. Pemeriksaan enzimatik HGPRTase dan PRPP sintetase dapat dilakukan pada kasus tertentu untuk memastikan diagnosis penyakit. ${ }^{17}$

Kelemahan dari penelitian ini yakni tidak diteliti mengenai pola konsumsi makanan dan minuman yang mengandung purin dalam jumlah yang besar. Hal ini berhubungan dengan sumber purin eksogen yang masuk ke dalam tubuh manusia. Selain itu, tidak dilakukan pemeriksaan kadar asam urat urin per 24 jam untuk mengetahui penyebab hiperurisemia baik produksi yang berlebihan maupun ekskre-si asam urat yang berkurang. Pemeriksaan enzim HGPRTase dan PRPP sintetase perlu juga dilakukan untuk membuktikan adanya peranan faktor genetik pada kejadian hiperurisemia yang terjadi. Jumlah sampel dalam penelitian perlu juga ditambah untuk meningkatkan validitas penelitian.

\section{SIMPULAN}

Dari penelitian ini dapat disimpulkan bahwa sebagian besar $(96,8 \%)$ responden mahasiswa angkatan 2011 Fakultas Kedokteran Universitas Sam Ratulangi dengan indeks massa tubuh 18,5-22,9 $\mathrm{kg} / \mathrm{m}^{2}$ mempunyai kadar asam urat darah dalam batas yang normal.

\section{UCAPAN TERIMA KASIH}

Ucapan terima kasih disampaikan pada: dr. Yanti Mewo, MPdKed, dr. Youla Assa, MKes,dan pada semua pihak yang baik secara langsung maupun tidak langsung telah menumbuhkan ide atau gagasan dalam pemikiran penulis sehingga dapat menyelesaikan artikel ini.

\section{DAFTAR PUSTAKA}

1. Larocque PL. Gout and hyperuricemia. 
CME bulletin.2009;8(2):1-5.

2. Terkeltaub R, Zelman D, Scavulli J, Perez-Ruiz F, Liote' F. Gout study group: update on hyperuricemia and gout. Joint Bone Spine. 2009;76:444-6.

3. Heinig M, Johnson RJ.Role of uric acid in hypertension, renal disease, and metabolic syndrome. Cleve Clin JMed. 2006;73:1059-64.

4. Zhu Y, Pandya BJ, Choi HK. Prevalence of gout and hyperuricemia in the US general population. Arthritis Rheum. 2011;63:3136-41.

5. Hong SJ, Kim YS, Kim HS. Prevalence and clinical features of hyperuricemia in gwangju and jeonnam territories. Journal of Rheumatic Diseases. 2012;19:138-46.

6. Putra IMR, Putra TR. Korelasi antara konsumsi alkohol dan fractional uric acid clearance pada populasi suku bali di desa panglipuran, kubu, bangli. J Peny Dalam. 2010;11:164-70.

7. Rotty LWA. Gambaran asam urat pada suku Minahasa usia dewasa muda (Thesis). Bagian Ilmu Penyakit Dalam. Manado: Fakultas Kedokteran Universitas Sam Ratulangi; 1999.

8. Gugliucci A, Thornburg R. Biosynthesis and degradation of nucleotides. In: Baynes JW, Dominiczak MH. Medical Biochemistry. $\quad 3^{\text {rd }}$ ed. McGraw-Hill; 2009.p.403-9.

9. Putra TR. Hiperurisemia. Dalam: Sudoyo AW, Setiyohadi B, Alwi I, Simadibrata M, Setiati S. Buku Ajar Ilmu Penyakit Dalam. $5^{\text {th }}$ ed. Vol. 3. Jakarta: Pusat Penerbitan Departemen Ilmu Penyakit Dalam FKUI; 2009. hal.2550-4.

10. Wortmann R. Disorders of Purine and Pyrimidine Metabolism. In: Fauci A, Braunwald E, Kasper D, Hauser S, Longo D, Larry Jameson J, Loscalzo J. Harrison’s
Principles of internal medicine. $17^{\text {th }} \mathrm{ed}$. Vol. 2. McGraw-Hill; 2008. p.2444-8.

11. Inoue $S$, Zimmet $P$, Caterson I, Chunming C, Ikeda Y, Khalid AK, et al. The Asia-Pacific perspective: Redefining obesity and its treatment. Australia: Health Communications; 2000.p.15-21.

12. Dirken-Heukensfeldt KJMJ, Teunissen TAM, van den Lisdonk EH, LagroJanssen ALM. Clinical features of woman with gout arthritis. Clin Rheumatol. 2010;29:575-82.

13. Cassidy JT, Petty RE. Musculoskeletal manifestations of systemic disease. In: Cassidy JT, Laxer RM, Petty RE, Lindsley CB. Textbook of Pediatric Rheumatology. $6^{\text {th }}$ ed. Philadelphia: Saunders Elsevier; 2011.p.615-41.

14. Choi HK, Ford ES. Prevalence of the metabolic syndrome in individuals with hyperuricemia. Am Med. 2007;120:442-7.

15. Cai Z, Xu X, Wu X, Zhou C, Li D. Hyperuricemia and the metabolic syndrome in Hangzhou. Asia Pac J Clin Nutr. 2009;18(1):81-7.

16. Premgamone $A$, Ditsatapornjaroen $T$, Jindawong B, Krusun N, Kessomboon P. The prevalence of hyperuricemia and associated factors in the rural community, Khon Kaen Province. Srinagarind Med J 2011;26(1):41-7.

17. Dincer HE, Dincer AP, Levinson DJ. Asymptomatic hyperuricemia treat or no treat. Cleve ClinJMed. 2002;69(8):594608.

18. García-Pavía $P$, Torres $R J$, Rivero $M$, Ahmed M, García-Puig J, Becker MA. Phosphoribosylpyrophosphate synthetase overactivity as a cause of uric acid overproduction in a young woman. Arthritis Rheum. 2003;48:2036-41. 